\title{
A Systematic Literature Review on Mergers and Acquisitions: A Bibliometric Analysis Approach
}

\author{
Godswill Osagie Osuma ${ }^{1}$, Ochei Ailemen Ikpefan ${ }^{1}$, Olawale Yinusa Olonade $^{2} \&$ Abimbola Abosede Joshua $^{3}$ \\ ${ }^{1}$ Department of Banking and Finance, Covenant University, Ota, Ogun State, Nigeria \\ 2 Department of Sociology, Covenant University, Ota, Ogun State, Nigeria \\ ${ }^{3}$ Department of Accounting, Mountian Top University, Nigeria \\ Correspondence: Godswill Osagie Osuma, Department of Banking and Finance, Covenant University, Ota, Ogun \\ State, Nigeria.
}

Received: August 19, 2020

Accepted: November 4, 2020

Online Published: April 8, 2021

doi:10.5430/ijfr.v12n4p125

URL: https://doi.org/10.5430/ijfr.v12n4p125

\begin{abstract}
Many studies have examined the effects of mergers and acquisitions, but their results vary significantly. Thus, mergers and acquisitions are one of the most popular corporate restructuring activities undertaken by various organizations, institutes, companies (both private and public), agencies, and establishments, all in a quest to achieve the desired aim of the companies. But a pertinent question exists as to if mergers and acquisitions (M\&A) have produced the desired goals and objectives of the companies. Therefore this study aims to examine the results, empirical preference, and author's opinions of existing literature as to if M\&A had produced synergy gains or not. Bibliometric analysis is the methodological procedure used in this study. A total number of fifty (50) high-profile literatures were qualitatively examined, and it shows that M\&A produced synergy gains to the level of $48 \%$. From the analysis, M\&A was also found not to produce synergy gain to the level of $28 \%$, thus making the remaining $24 \%$ to be associated with authors whose views weren't explicit and those that are undecided to M\&A producing synergy gains. This review study recommends that horizontal mergers and acquisitions be encouraged to increase the companies' market share, leading to their desired goals and objectives.
\end{abstract}

Keywords: mergers and acquisition, bibliometric review, synergy, performance

JEL Codes: G20, G21, G34, Y1

\section{Introduction}

Mergers and acquisitions (M\&A) are one of the most subscribed corporate restructuring activities aimed to strengthen the current position of a firm and achieve its set strategic aims and objectives. A firm's established strategic goals and objectives might be to expand into new markets to gain competitive advantage, economies of scale, and incorporate innovative technologies (Schuler \& Jackson, 2001). Over the years, synergy gains have been found to strive with Mergers and Acquisition (Hagedoorn \& Duysters, 2002; Basmah \& Rahatullah, 2013; Bauer; King \& Matzler, 2016). On the other hand, it has also been concluded not to produce synergy gains (Cartwright \& Schoenberg, 2006; doytch \& Cakan, 2011; Ahmed \& Ahmed, 2014; Ajayi \& Obisesan, 2016). Synergy gains go far beyond the traditional $1+1=3$ or $2+2=5$. It merely represents that the initial purpose of the merger is achieved not just in size expansion but also in making economies of scale, reducing market competition, enhancing the acquiring firm's proliferation, increased market share, and a more integrated value chain. It is a fact that mergers and acquisitions are synonymous or interwoven; they also share similarities and differences before any company can venture into adopting any of the terms; such a company must understand the two concepts individually and collectively. The advantages and disadvantages of the proposed M\&A must be known as well as the complexities.

Mergers and acquisitions have varied over the last ten decades. It has changed and influenced the generality of today's ways of doing business. It has affected to no small extent positively the economic, financial, and global market conditions. However, it has its negative influences. Merger and Acquisition have forced companies to fold up, change their perspectives on business culture and value, synergy building to make more profits, and have giant tentacles of market waves under a single authority and brand. A merger is a conditional decision for sustainability that occurs between two companies to become one entity where terms and conditions are spelled out, and 
shareholders give their consent for the merger or Acquisition as the case may be. The two companies' shareholders submit their shares for the growth and development of the new business empire. In a purchase, the bidding company raises finances for the tender offer through the issue of new debt or equity, which may be in the form of cash and kind. Acquisition on its part may be friendly (when the share and stakeholders of the respective companies are willing to give in for purchase). It may be otherwise (when they decline to consent to the newfound concept, most importantly, when it does not bring them more dividends). In an acquisition of shares and assets, the bidding company acquires the target company's shares and investments.

Mergers and acquisitions provide an avenue to synergize by sharing operational activities, manufacturing facilities, and distribution systems. The primary goal for merger and Acquisition is to achieve the firm's objectives collectively as against companies separated for more fabulous and more robust efficiency, improvement, and higher performances. It also serves as a secure business platform for added financial value and a broader horizon in the business world. The vast majority of M\&A pieces of literature focused on, more prominent, United States publicly traded corporations that used archival data (Haleblian, Devers, Mcnamara, Carpenter, Robert \& Mcnamara, 2009). The scope of this study was not limited to the U.S.A alone. Still, a vast consideration and in-depth analysis were used in considering the corporate restructuring activities of M\&A in other countries. The study's objective is to examine if M\&As have produced synergy gains through a systematic review of works of literature. This study's question is in line with the research aim (objective). The study hypothesis is stated in its null $\left(\mathrm{H}_{0}\right)$ form.

\subsection{Research Hypothesis}

$\mathrm{H}_{0}$ : Mergers and acquisitions do not significantly produce synergy gains.

\section{Review of Literature}

Vennet (1996) examined M\&A effects on the profitability and efficiency of the European Community (E.C.) credit organization, where his sample was based on four hundred and ninety-two (492) takeovers. He found that equal-sized partners (banks) involved in local/ domestic mergers improved the merger's performance, while cross-border Acquisition improved the firm's cost efficiency. Ikpefan (2012) examined the post-consolidation effects of M\&As on the Nigerian deposit money banks, and he found from his results that M\&As affected the bank's performance positively. Ikpefan (2012) recommended that deposit money banks managers be more efficient and effective in allocating resources to remain relevant to the industry's stiff competition. Gattoufi, Al-Muharrami, and Al-kiyumi (2009) examined the impacts of M\&A's on the efficiency of the Gulf Cooperation Council (G.C.C.) commercial banks. They found that M\&As has a positive effect on the performance of the forty-two (42) G.C.C. banks used as a case study. The G.C.C. comprises the inter-governmental economic and political regional union, which consists of the Arabian Gulf states except for Iraq. The six countries that constitute the G.C.C. are; Qatar, Oman, Saudi Arabia, Bahrain, the United Arab Emirates (U.A.E.), and Kuwait. Jayadev and Sensarma (2007) examined M\&A in the Indian banking system, considering two critical stakeholders' viewpoints: the managers and shareholders. They carried out an event study that showed that in the case of forced M\&A, both the acquiring and the acquired bank's shareholders did not benefit from the consolidation process. In contrast, in the event of a voluntary M\&A, the acquiring bank's shareholders seem to gain more than the acquired bank's shareholders.

From the viewpoint of the managers, the managers are keen on the increased valuation of the loan portfolio, integration of I.T. platforms, e.tc; as the key benefits of M\&As. Their viewpoints on the essential stakeholders corroborate with the assertions of Osuma, Ikpefan, Osabohien, Ndigwe, and Nkwodimmah (2018), which states that bank managers usually strive to balance the tradeoff between their shareholders who are keen on-demand dividend and customers who are keen on demand deposits. Goyal and Joshi (2012) examined mergers and acquisitions in India's banking industry, taking the ICICI Bank Ltd as a case study. They stated that M\&A is used as a strategy to maintain and strengthen the firm's position in the market place. They further concluded that these consolidations could birth menaces such as; personal trauma and stress, which would result in psychological and survival problems for both the individuals involved and companies. Kumari (2014) also assessed the impact of M\&A in the Indian Banking industry to investigate the banks positioning before (pre) and after (post) merger. He posited that the merged entities grow more after (post) the M\&A when compared to their state before (pre) the mergers, which were characterized by an increase in branch proliferation, increases deposits, and profit after tax.

Joash and Njangiru (2015) posited that studies on M\&A have not conclusively established whether or not banks benefit from M\&As. They examined the effects of M\&A on banks' financial performance. They further surveyed fourteen (14) deposit money banks in Kenya involved in a consolidation process; they found a significant increase in the profitability and shareholders' value of the merged banks under review. Hitt, Ireland, and Harrison (2008) undertook a similar study on M\&A if it was a value-creating strategy or a destroying strategy? They concluded by 
positing that the environment in which M\&A's takes place is constantly changing. Therefore some attributes such as due diligence, poor governance, e.tc; seem to affect the consolidation process negatively. He recommended that areas that would test the influence of M\&A on stakeholders (e.g., suppliers, communities, employees, e.tc.) should be explored.

Mergers and Acquisitions have failed to achieve the forecasted financial synergy of $2+2=5$ increase (Hover, 1973). However, the United States and Britain have experienced waves of M\&A activities, which dates as far back as 1893 to early 2000, where thousands of M\&A's were registered. The results of this consolidation exercises lead to one in four of the United States of America's workforce to be adversely affected, which lead to their retrenchment (Fulmer, 1986). Berger, Saunders, Scalise, and Udell (1998) examined the effects of bank M\&A's on small business lending using data from six thousand (6000) United States banks M\&A's. They found out that consolidation reduces small business lending. Just as mergers and Acquisitions have transformed in other disciplines, finance researchers have focused on answering the dilemma of whether M\&A are wealth reducing or wealth-creating events for shareholders (Cartwright \& Schoenberg, 2006). Reddy (2015) carried out a research on case study approach on M\&A literature where he examined ninety-three (93) articles that explored the case study approach out of which he concluded that topical themes like; motives behind unsuccessful M\&A in both domestic and cross-border settings, cultural issues and challenges that go beyond cross-border were researched e.tc.

Sharma (2018) examined the effects of Mergers and Acquisition on Banks in Nepal. He employed both primary data to source information from employees and secondary data to analyze M\&A effects on shareholder's wealth. He used critical indicators from the bank's financial statements to analyze its financial performances. Out of the three banks he used as a case study which includes; NIC ASIA Bank Ltd, Machhapuchhre Bank, and Global Bank Ltd he found that mergers and Acquisition has a positive impact on both the human factors and it aids the financial performance of the selected banks. Sujud and Hachem (2018) carried out a study on the effects of M\&As on Lebanese Banks Performance. Their result showed that the bank's return on equity (R.O.E.) and return on assets (ROA) had an insignificant increase. Also, they found that the mergers had no significant increase in the shareholder's equity while there was a significant positive impact on earnings per share.

In time past, the Nigerian banking industry has experienced a series of reforms to support the real economy. Implementing these reforms has sometimes led to a reduction in the number of banks operating in the industry (Okoye, Modebe, Achugamonu, and Isibor, 2016). Just as the banking recapitalization reform led to mergers, acquisitions, and take-overs shrank the eighty-nine (89) banks to twenty-five (25) deposit money banks after the exercise. Awan and Mahmood (2015) averred that M\&A's are practiced worldwide by businessmen and women for the accomplishment of their business enlargements, endurance, and personal business objectives. Ajayi and Obisesan (2016) carried out a study on the effects of M\&A on selected deposit money banks in Nigeria. They used total deposits as their explanatory variable and profit after tax as their explained variable. The result of their findings showed that M\&As has no significant effects on the performance of their case study banks. Hagedoorn and Duysters (2002) examined the impact of M\&A on the technological achievement of companies in a High-tech environment. They found that the organizational and strategic fit associated with Mergers and Acquisitions plays a significant role in improving the companies' post-merger technological performance. Cartwright and Schoenberg (2006) stated that there might be three possible causes for the lack of synergy gains experienced in previous mergers and acquisition exercise over the years:

i. Top executives undertake M\&A with non-value maximizing motives.

ii. The views, findings, and recommendations of academic researchers are not reaching and positively impacting practice.

iii. There is a lack of updated research in M\&A.

Firstly, some M\&As are driven by the top executives' selfish and perquisite gains, which would result in non-value maximizing motives. Seth, Song, and Pettit (2000) examined the United States' cross-border acquisitions. He found that twenty-six percent (26\%) were initiated by the top managers for their selfish gains and utility rather than the interest of the shareholders as cited in (Cartwright \& Schoenberg, 2006). Therefore the main motive of any M\&A should be based primarily on value-creating opportunities that are forecasted. Secondly, they tend to be a hiatus between theory and practice; this is why most practitioners are unaware of researchers' valid recommendations. Finally, this study critics the third point, which states that "There is a paucity of updated research on M\&A." Empirically, there is no lack or paucity of research in M\&A because numerous studies have been carried out on the concept cut across various sectors and industries both domestically and cross-border forms. 
Joshua (2011) examined the impact of M\&A on the financial efficiency of banks in Nigeria. He carried out a comparative analysis between the pre-M\&A and post M\&A periods of three (3) selected banks using profit after tax, net assets, and gross earnings as proxies. His findings showed that the post M\&A periods were more efficient financially compared to the pre-M\&A periods. Oloye and Osuma (2015) examined the impacts of M\&A on the performance of Nigerian Banks, where they made use of two deposit money banks in Nigeria. They used shareholders' funds and profit after tax as proxies for the financial efficiency for both the pre and post-consolidation era with a base year. They concluded that M\&A should not be seen as a universal remedy for strengthening the financial standing of firms, but rather a relevant tool for attaining the organizational objectives of both firms.

Most employees feel insecure during consolidation exercises, especially when it has to do with either Acquisition or takeover. Most of them think they would either be; retrench, laid-off, demoted, e.tc. This rational behavior made Schweizer and Patzelt (2012) empirically examine the commitment of employees' after the acquisition process, emphasizing the integration speed and leadership. Their analysis showed that fast consolidation integration would positively affect the employees because they would be motivated to stay with the firm. From their study, it was found that the post-consolidation integration benefits outweigh the pre-consolidation position of the firm. Integration speed has been cited more frequently to be a significant success factor for acquisitions (Bauer, King, and Matzler, 2016). Correia, Cunha, and Scholten (2013), in their study, examined how M\&A affects the centrality of human resource management moderates organizational performance. Bidder, target acquisition, and mergers were identified as the three (3) categories of M\&A ownership change. They concluded that M\&As should be further researched from the three types of ownership changes. Meglio, King, and Risberg (2017) examined the role integration speed plays in M\&A across the consolidation process, and they found that integration speed is a pertinent element during the success of the M\&A process. However, they opined that further studies should be carried out to determine the time and extent of change achieved after the acquisition process.

Research carried out by Satish and lalil (2008) from the Indian context, on the impact of mergers and Acquisition on corporate performance in India considering a large number of cases revealed that mergers and Acquisition generate synergy in the long run which may result in higher cash flow, diversification, increase in business and reduction of cost. Rashid and Naeem (2017) examined the effects of mergers and Acquisition on corporate performance in the Pakistan context using the deal data covering the period of 1995-2012 (13 years); the result showed that the alliance has an insignificant effect on profitability, liquidity and leverage position of the organizations. However, mergers and acquisitions have a negative but significant impact on the acquirer firms' quick ratio. In the United Kingdom context, the study of Jallow, Masazing, and Basit (2017) considered the effects of mergers and acquisitions on U.K. companies' financial performance using 40 listed companies. The study compared five (5) years pre-merger and Acquisition, and five (5) years post-merger period and Acquisition. The proxies for financial performance include return on equity, return on assets, earnings per share, and net profit margin. The result showed that mergers and acquisitions positively and significantly impact earnings per share, return on assets, and return on equity. Therefore, it enhances financial synergy.

Joash and Njangiru (2017) examined the effects of Mergers and Acquisition on commercial banks' financial performance in Kenya. All the fourteen (14) merged banks in Kenya were investigated covering 2000-2014 (15 years), which revealed that mergers and Acquisitions enhance an increase in shareholders' value of the acquiring banks and positively and significantly impact profitability. Therefore, mergers and acquisition practices in the Kenya context increased those commercial banks' financial performance. The research exercise carried out by Voesenek (2014) in the global context considering the countries around the world and making an international comparison between crisis and non-crisis period. The study revealed that the effects of mergers and acquisitions are the same across states, which indicates that firms in different countries have the same impact on shareholders' wealth and post-merger profitability. The result showed that the target shareholders have more substantial wealth effects than the acquirer shareholders. Also, the forces during the crisis period outperform the non-crisis period. Finally, a mere announcement of mergers and acquisitions has positive effects on the stock price. However, Voesenek (2014) study contrasts with the study of Derrien, Fresard, Slabki, and Valta (2017), which stated that announcement of Mergers and Acquisition in the United States have robust adverse effects on the stock price of industry rivals in the U.S. This negative effect resulted in decreased returns and overall business performance, which in the long run, increase the probability of bankruptcy and future rivals' Acquisition. Therefore, mergers and acquisitions have a robust competitive effect on the competitors of the target company.

Basmah and Rahatullah (2013) study, the financial synergy in mergers and acquisitions in Saudi Arabia, revealed that Saudi Arabia companies engaged in mergers and acquisitions majorly to achieve synergy. This is done through more market power gained from the synergy effect, which is, as a result, increased firm size, which was an outcome 
of mergers. Saudi Arabia companies obtained synergy as a result of combined resources derived from M\&As. Also, economies of scale, as well as economies of scope, were achieved. Economies of scope is a situation whereby the cost of producing two goods and services by a multi-product company is less than producing the products and services individually by two single-product firms. The study of Maditinos, Theriou, and Demetriades (2009) in the Greek context revealed that the merged banks have a synergy effect as it enhances profitability and competitive advantage.

Contrary to this finding was the study of Ahmed and Ahmed (2014) that stated that companies in Pakistan never had a synergy gain through mergers and acquisitions because M\&As had an insignificant effect on profitability, liquidity, and capital position of those companies. Also, there was a deterioration of efficiency after the merger period. The research carried out by Rani, Yadav, and Jain (2015) in India revealed that acquiring companies experienced positive abnormal returns to their investors before the announcement of mergers and acquisitions. However, this abnormal return never sustains after the report. Therefore, synergy gains did not exist. The study of Eric (2015) was carried out to consider the synergy effect of mergers and acquisitions on the insurance company's performance in Kenya. Their research revealed that profitability increased consistently even after mergers and acquisitions of the companies involved. However, the study revealed that the significant profit growth was a result of other factors outside M\&As. The study also showed that new markets were obtained, operational efficiency was enhanced, and quality leadership was achieved after the merger, and increased customer loyalty.

Waddock and Graves (2006) posited that mergers and acquisitions on corporate stakeholders' practices include diversity, corporate governance, the environment, employees, and product in the American context. The study revealed that merged companies showed more strength in diversity and the environment due to the target and acquiring companies' size. Eliasson's (2011) survey on synergies in mergers and acquisitions, a qualitative study of the technical trading company, revealed that the combined companies experience combined synergy due to the balance between revenue synergy and cost synergy that is revenue enhancement and cost savings. The study of Blonigen and Pierce (2016) determined the effect of mergers and acquisitions on the markup and the productivity of plants and firms of all United States manufacturing companies. The study revealed that mergers and acquisition activities improved profit on average. Still, there is little evidence of the impact of M\&As activities on the productivity of plants of these companies on average. The research exercise of Mboroto (2013) to determine the effects of mergers and acquisitions on the performance of petroleum companies in Kenya revealed that M\&A had a significant effect on the return on assets (ROA), which stands as the overall standard measure of the merged firm. However, M\&A had an insignificant impact on the liquidity and solvency of petroleum firms under consideration. Therefore, the study believed that M\&As could be used to enhance competitiveness and financial sustainability.

The study of doytch and Cakan (2011) to unravel the effect of growth mergers and Acquisition of the OECD countries' economic growth. The study revealed that on the aggregate, M\&A has no positive contribution to the economic growth of these countries except for the growth of the services sector. At the same time, it negatively impacted the growth of the primary and manufacturing industries. The industries under consideration include the primary industry, manufacturing, and services. The research carried out by Udeh and Igwe (2013) in the Nigerian context to determine the effects of mergers and acquisitions on return on capital employed and dividend per share indices of companies. The result revealed that mergers and acquisitions impacted the earnings per share than on the return on capital employed. Therefore, the study recommended that to enhance profitability, companies should embark on mergers and acquisitions. However, the survey carried out in Croatia by Pervan, Visic, and Barnjak (2015), considering the period of 2008-2011 (4 years) revealed that mergers and acquisitions had an insignificant effect on the target companies when compared their performance before and after the merger even with their peer companies. Lakstutiene, Stankeviciene, Norvaisiene, and Narbutiene (2015) evaluated the impact of the Acquisition on corporate performance results during the economic slowdown period in Lithuania. The result revealed that Acquisition during the period of the financial meltdown in Lithuania is beneficial. Mager and Meyer-Fackler (2017) examined the effect of mergers and acquisitions in Germany, considering the period of 1981-2010. The study revealed the first sub-sampled period of 1981-1990 indicated a positive abnormal return for the companies involved in M\&A when compared with their peers. However, in the long run, M\&A did not show a significant negative abnormal performance for the full period under consideration.

\section{Methodological Procedures}

Content analysis (bibliometric analysis) was adopted for this study. Thus, Chain, Santos, Junior, and Prado (2019) said that bibliometric analysis is usually applied to knowledge fields that are useful and important for the 
understanding of the dynamics and aids to visualize the trends in scientific production robustly. The pieces of literature reviewed in this study gives a bird's eye view on the pattern of M\&A domestically and globally

\subsection{Source of Data Collection}

This study is based on secondary data, which were sourced from the opinions, results, decisions, and stands of authors who have embarked on similar research on M\&A's. The longitudinal study includes; published articles, books, and periodical materials, over the years.

\section{Results and Discussion}

From the literature reviewed the authors' opinions were categorized into three namely;

i. The authors who supported M\&A to produce synergy gains.

ii. The authors that did not support M\&A to produce synergy gains.

iii. Those that where undecided as to if M\&A produced synergy gains or not. These would give the readers a quick bird eye view of the results presented in Tables 1 and 2 .

Table 1. Finding

\begin{tabular}{llllll}
\hline & & Frequency & Percent & Valid Percent & Cumulative Percent \\
\hline Valid & Synergy gain & 24 & 48.0 & 54.5 & 54.5 \\
\cline { 2 - 6 } & No synergy gain & 14 & 28.0 & 31.8 & 86.4 \\
\cline { 2 - 6 } & Undecided & 6 & 12.0 & 13.6 & 100.0 \\
\cline { 2 - 6 } & Total & 44 & 88.0 & 100.0 & \\
\hline Missing & System & 6 & 12.0 & & \\
\hline Total & & 50 & 100.0 & & \\
\hline
\end{tabular}

Source: SPSS Output, (2019)

From Table 1, the study found that out of the fifty (50) findings of the authors, twenty-four (24) authors agreed that Mergers and Acquisitions had produced synergy gains culminating to $48.0 \%$. Fourteen (14) authors thought that Mergers and Acquisitions had not produced synergy gains, thus culminating to 28\%, six (6) authors were undecided as to if Mergers and Acquisitions had synergy gains or not, thus culminating to $12 \%$. The remaining six (6) authors weren't explicit with their findings as to if M\&A's had synergy gains or not, thus captured as a missing system.

Table 2. Author's views on mergers and acquisition

\begin{tabular}{llllll}
\hline S/n & Authors & Years & Findings & Valid $\%$ & Cumulative $\%$ \\
\hline 1 & Ahmed and Ahmed & 2014 & NSG & 2.0 & 2.0 \\
\hline 2 & Ajayi and Obisesan & 2016 & NSG & 2.0 & 4.0 \\
\hline 3 & Awan and Mahmood & 2015 & U & 2.0 & 6.0 \\
\hline 4 & Basmah and Rahatullah & 2013 & SG & 2.0 & 8.0 \\
\hline 5 & Bauer, King, and Matzler & 2016 & SG & 2.0 & 10.0 \\
\hline 6 & Berger, Saunders, Scalise, et al & 1998 & NSG & 2.0 & 12.0 \\
\hline 7 & Blonigen and Pierce & 2016 & SG & 2.0 & 14.0 \\
\hline 8 & Cartwright and Schoenberg & 2006 & NSG & 2.0 & 16.0 \\
\hline 9 & Correia, Cunha, and Scholten & 2013 & U & 2.0 & 18.0 \\
\hline 10 & Derrien, Fresard, Slabki, et al & 2017 & NSG & 2.0 & 20.0 \\
\hline 11 & doytch and Cakan & 2011 & NSG & 2.0 & 22.0 \\
\hline 12 & Eliasson & 2011 & SG & 2.0 & 24.0 \\
\hline
\end{tabular}




\begin{tabular}{|c|c|c|c|c|c|}
\hline 13 & Eric & 2015 & SG & 2.0 & 26.0 \\
\hline 14 & Fulmer & 1986 & NSG & 2.0 & 28.0 \\
\hline 15 & Gattoufi, Al-Muharrami, and Al-kiyumi & 2009 & SG & 2.0 & 30.0 \\
\hline 16 & Goyal and Joshi & 2012 & NSG & 2.0 & 32.0 \\
\hline 17 & Hagedoorn and Duysters & 2002 & SG & 2.0 & 34.0 \\
\hline 18 & Haleblain, Dever, Mcnamara, et al & 2009 & $\mathrm{NE}$ & 2.0 & 36.0 \\
\hline 19 & Harford & 2005 & $\mathrm{NE}$ & 2.0 & 38.0 \\
\hline 20 & Hitt, Ireland, and Harrison & 2008 & NSG & 2.0 & 40.0 \\
\hline 21 & Hover & 1973 & NSG & 2.0 & 42.0 \\
\hline 22 & Ikpefan & 2012 & SG & 2.0 & 44.0 \\
\hline 23 & Jallow, Masazing, and Basit & 2017 & SG & 2.0 & 46.0 \\
\hline 24 & Jayadev and Sensarma & 2007 & $\mathrm{U}$ & 2.0 & 48.0 \\
\hline 25 & Joash and Njangiru & $\begin{array}{l}2015 \\
\& 2017\end{array}$ & $\begin{array}{l}\text { S.G. } \\
\text { SG }\end{array}$ & 2.0 & 50.0 \\
\hline 26 & Joshua & 2011 & SG & 2.0 & 52.0 \\
\hline 27 & Kumari & 2014 & NSG & 2.0 & 54.0 \\
\hline 28 & Lakstutiene, Stankeviciene, Norvaisiene, et al & 2015 & SG & 2.0 & 56.0 \\
\hline 29 & Maditinos, Theriou and Demetriades & 2009 & SG & 2.0 & 68.0 \\
\hline 30 & Mager and Meyer-Fackler & 2017 & SG & 2.0 & 60.0 \\
\hline 31 & Mboroto & 2013 & SG & 2.0 & 62.0 \\
\hline 32 & Meglio, King and Risberg & 2017 & SG & 2.0 & 64.0 \\
\hline 33 & Mitchell and Mulherin & 1996 & $\mathrm{NE}$ & 2.0 & 66.0 \\
\hline 34 & Okoye, Modebe, Achugamonu, et al & 2016 & $\mathrm{NE}$ & 2.0 & 68.0 \\
\hline 35 & Oloye and Osuma & 2015 & $\mathrm{U}$ & 2.0 & 70.0 \\
\hline 36 & Osuma, Ikpefan, Osabohien, et al & 2018 & SG & 2.0 & 72.0 \\
\hline 37 & Pervan, Visic, and Barnjak & 2015 & NSG & 2.0 & 74.0 \\
\hline 38 & Rani, Yadav, and Jain & 2015 & $\mathrm{U}$ & 2.0 & 76.0 \\
\hline 39 & Rashid and Naeem & 2017 & NSG & 2.0 & 78.0 \\
\hline 40 & Reddy & 2015 & $\mathrm{NE}$ & 2.0 & 80.0 \\
\hline 41 & Satish and lalil & 2008 & SG & 2.0 & 82.0 \\
\hline 42 & Schweizer and Patzelt & 2012 & SG & 2.0 & 84.0 \\
\hline 43 & Seth, Song, and Pettit & 2000 & $\mathrm{U}$ & 2.0 & 86.0 \\
\hline 44 & Sharma & 2018 & SG & 2.0 & 88.0 \\
\hline 45 & Shleifer and Vishny & 2003 & $\mathrm{NE}$ & 2.0 & 90.0 \\
\hline 46 & Sujud and Hachem & 2018 & NSG & 2.0 & 92.0 \\
\hline 47 & Udeh and Igwe & 2013 & SG & 2.0 & 94.0 \\
\hline 48 & Vennet & 1996 & SG & 2.0 & 96.0 \\
\hline 49 & Voesenek & 2014 & SG & 2.0 & 98.0 \\
\hline \multirow[t]{2}{*}{50} & Waddock and Graves & 2006 & SG & 2.0 & 100 \\
\hline & Total & 50 & & 100.0 & \\
\hline
\end{tabular}

Source: Author's Computation (2019)

Note: "N.S.G. means- no synergy gains," "S.G. means- synergy gains," "U means- Undecided," "N.E. means- Not explicit." 


\section{Conclusion}

We have found that the study of mergers and acquisitions from scholars had mixed results within and without. Most misguided M\&A often gives the prey more benefits than the predator, especially where the financials of the prey company had losses and low price-earnings ratio. This study has shed light on existing literature and is expected to guide corporate entities on M\&A to enable such entities to continue to exist as a going concern entity. A business's sustainability is based on qualitative service delivery and utility derived from the goods or products. Thus, mergers and acquisitions are one of the most practiced corporate restructuring activities spurred towards achieving the firms' desired objectives.

\section{Acknowledgment}

The authors use this medium to appreciate Covenant University Centre for Research Innovation and Discovery for providing the article-processing charge of this article.

\section{References}

Ahmed, M., \& Ahmed, Z. (2014). Mergers and Acquisition: The effects on financial performance of manufacturing companies in Pakistan. Middle-East Journals of Scientific Research, 21(4), 689-699.

Ajayi, L. B., \& Obisesan, O. G. (2016). The effect of merger and Acquisition on the performance of banks in Nigeria. Journal of Economics and International Business Management, 4(1), 22-29.

Awan, G. A., \& Mahmood, U. B. (2015). Impact of mergers and acquisitions on the performance of commercial banks in Pakistan. Journal of Poverty, Investment, and Development, 16(2), 48-56.

Basmah, A. Q., \& Rahatullah, M. K. (2013). Financial synergy in mergers and acquisitions in Saudi Arabia. Journal of Finance, 8(15), 181-192.

Bauer, F., King, D., \& Matzler, K. (2016). Speed of acquisition integration: Separating the role of human and task integration. Scandinavian Journal of Management, 32(3), 150-165. https://doi.org/10.1016/j.scaman.2016.08.001

Berger, A. N., Saunders, A., Scalise, J. M., \& Udell, G. F. (1998). The effects of bank mergers and acquisitions on small business lending. Journal of Financial Economics, 50(1998), 187-229.

Blonigen, B. A., \& Pierce, J. R. (2016). Evidence for the effects of mergers on market power and efficiency. National Bureau of Economic Research. Working Paper 22750. Retrieved from https//:www.nber.org/papers/w22750

Cartwright, S., \& Schoenberg, R. (2006). Thirty years of mergers and acquisitions research: recent advances and future opportunities. British Journal of Management, 17, 1-5. https://doi.org/10.1111/j.1467-8551.2006.00475.x

Chain, C. P., Santos, A. C., Junior, L. G., \& Prado, J. W. (2019). Bibliometric Analysis of the quantitative methods applied to the measurement of industrial clusters, Journal of Economic Survey, 33(1), 60-84. https://doi.org/10.1111/joes.12267

Correia, M. F., Cunha, R. C. E., \& Scholten, M. (2013). Impact of M\&As on organizational performance: The moderating role of H.R.M. centrality. European Management Journal, 31(4), 323-332. https://doi.org/10.1016/j.emj.2013.01.004

Derrien, F., Fresard, L., Slabik, V., \& Valta, P. (2017). The adverse effects of mergers and acquisition on the value of rivals. Seminar Paper.

Doytch, N., \& Cakan, E. (2011). Growth effects of mergers and Acquisition: A sector-level study of OECD countries. Journal of Applied Economics and Business Research, 1(3), 120-129.

Eliasson, S. (2011). Synergies in mergers and acquisitions a qualitative study of technical trading companies. MSc. Thesis.

Eric, V. (2015). Effects of mergers and acquisitions on growth of insurance firms in Kenya. MSc. Thesis.

Fulmer, R. (1986). Meeting the merger integration challenge with management development. Journal of Management Development, 5(4), 7-16.

Gattoufi, S., Al-Muharrami, S., \& Al-Kiyumi, A. (2009). The impact of mergers and acquisitions on the efficiency of G.C.C. banks. Banks and Bank Systems, 46(10), 1531-1543. https://doi.org/10.1108/00251740810920029

Goyal, K. A., \& Joshi, V. (2012). Merger and Acquisition in banking industry: a case study of ICICI Bank Ltd. 
International Journal of Research in Management, 2(2), 30-40.

Hagedoorn, J., \& Duysters, G. (2002). The effects of mergers and acquisitions on the technological performance of companies in a high-tech environment. Technology Analysis and Strategic Management, 14(1), 67-85. https://doi.org/10.1080/09537320220125892

Haleblian, J., Devers, C. E., Mcnamara, G., Carpenter, M. A., Robert, B., \& Mcnamara, G. (2009). Taking stock of what we know about mergers and acquisitions: a review and research agenda. Journal of Management, 35(3), 469-502. https://doi.org/10.1177/0149206308330554

Hitt, M. A., Ireland, R. D., \& Harrison, J. S. (2008). Mergers and acquisitions: a value creating or value destroying strategy?. The Blackwell Handbook of Strategic Management, 377-402. https://doi.org/10.1111/b.9780631218616.2006.00014.x

Hovers, J. (1973). Expansion through acquisition. Business Book Ltd, London.

Ikpefan, O. A. (2012). Post-consolidation effect of mergers and acquisitions on Nigerian deposit money banks. European Journal of Business and Management, 4(16), 151-162.

Jallow, M. S., Masazing, M., \& Basit, A. (2017). The effects of mergers and acquisitions on financial performance: case study of U.K. companies. International Journal of Accounting and Business Management, 5(1), 74-92.

Jayadev, M., \& Sensarma, R. (2007). Mergers in Indian banking: an analysis. South Asian Journal of Management, 14(4), 20-49. Retrieved from http://hdl.handle.net/2299/3465

Joash, G. O., \& Njangiru, M. J. (2015). The effect of mergers and acquisitions on financial performance of banks (A Survey of Commercial Banks in Kenya). International Journal of Innovative Research \& Development, 4(8), 101-113. https://doi.org/10.9790/487X-1908038490

Joshua, O. (2011). Comparative analysis of the impact of mergers and acquisitions on the financial efficiency of banks in Nigeria. Journal of Accounting and Taxation, 3(1), 1-7.

Kumari, P. (2014). Mergers and acquisitions in Indian banking sector - a strategic approach. Global Journal of Finance and Management, 6(3), 217-222.

Lakstutiene, A., Stankeviciene, J., Norvaisiene, R., \& Narbutien, J. (2015). The impacts of acquisitions on the corporate performance result during the period of economic slowdown: Case of Lithuania. 20 ${ }^{\text {th }}$ International Scientific Conference Economics and Management - 2015, Procedia of Social and Behavioural Sciences (pp. 455-460). https://doi.org/10.1016/j.sbspro.2015.11.433

Maditinos, D., Theriou, N., \& Demetriades, E. (2009). The effects of mergers and acquisitions on the performance of companies - The Greek case of Ioniki-Laiki Bank and Pistoes Bank. European Research Studies, 7(2), 111-130.

Mager, F., \& Meyer-Fackler, M. (2017). Mergers and Acquisitions in Germany: 1981-2010. Global Finance Journal, 34(2017), 32-42. https://doi.org/10.1016/j.gfj.2017.03.004

Mboroto, S. N. (2013). The effects of mergers and acquisitions on the financial performance of petroleum firms in Kenya. MSc. Thesis in Finance.

Meglio, O., King, D. R., \& Risberg, A. (2017). Speed in acquisitions: A managerial framework. Business Horizons, 60(3), 415-425. https://doi.org/10.1016/j.bushor.2016.12.004

Okoye, L. U., Modebe, N. J., Achugamonu, U., \& Isibor, A. (2016). Effect of mergers and acquisitions on banking sector performance in Nigeria. NG-Journal of Social Development, 5(5), 78-86.

Oloye, M. I., \& Osuma, G. (2015). Impact of mergers and acquisition on the performance of Nigerian banks (a case study of selected banks). Pyrex Journal of Business and Finance Management Research, 1(4), 23-40. Retrieved from https://www.pyrexjournals.org/pjbfmr/pdf/2015/november/oloye-and-osuma.pdf

Osuma, G., Ikpefan, A., Osabohien, R., Ndigwe, C., \& Nkwodimmah, P. (2018). Working capital management and bank performance: empirical research of ten deposit money banks in Nigeria. Banks and Bank Systems, 13(2), 49-61. https://doi.org/10.21511/bbs.13(2).2018.05

Pervan, M., Visic, J., \& Barnjak, K. (2015). The impact of M\&A on companies' performance.Evidence from Croatia. Procedia Economics and Finance, 23(2015), 1451-1456. http://doi.10.1016/S2212-5671(15)00351-2

Rani, N., Yadav, S. S., \& Jain, P. K. (2015). Impact of Mergers and Acquisition on shareholders' wealth in the short run: An event study approach. The Journal for Decision Makers, 40(3), 293-312. 
Rashid, A., \& Naeem, N. (2017). Effects of mergers on corporate performance: An empirical evaluation using O.L.S. and the empirical Bayesian method. Borsa Istanbul Review, 17(2017), 10-24.

Reddy, K. S. (2015). The state of case study approach in mergers and acquisitions literature: A bibliometric analysis. Future Business Journal, 1(1-2), 13-34. https://doi.org/10.1016/j.fbj.2015.09.001

Satish, K., \& Lalil, K. B. (2008). The impact of mergers and acquisitions on corporate performance in India. Management Decision, 46(10), 1531-1543. https://doi.org/10.1108/00251740810920029

Schuler, R. S., \& Jackson, S. E. (2001). H.R. Issues and activities in Mergers and Acquisitions. European Management Journal, 19(3), 239-253. https://doi.org/10.1016/S0263-2373(01)00021-4

Schweizer, L., \& Patzelt, H. (2012). Employee's commitment in the post-acquisition integration process: The effect of integration speed and leadership. Scandinavian Journal of Management, 28(4), 298-310.

Seth, A., Song, K., \& Pettit, R. (2000). Synergy, Materialism or Hubris? An Empirical Examination of Motives for Foreign Acquisitions of U.S. Firms. Journal of International Business Studies, 31(4), 387-405.

Sharma, K. P. (2018). Effect of banks' merger and acquisition in Nepal: Study of selected banks. KAAV International Journal of Law, Finance \& Industrial Relations, 5(1), 41-52.

Sujud, H., \& Hachem, B. (2018). Effect of mergers and acquisitions on performance of Lebanese banks. International Research Journal of Finance and Economics, 166(2018), 61-77.

Udeh, S. N., \& Igwe, N. N. (2013). Effects of mergers and acquisitions on return of capital employed and dividend per share indices of companies in Nigeria. International Journal of Business Administration, 4(5), 51-72.

Vennet, R. V. (1996). The effect of mergers and acquisitions on the efficiency and profitability of E.C. credit institutions. Journal of Banking and Finance, 20(1996), 1531-1558.

Voenesek, A. A. (2014). The effects of mergers and acquisitions on firms performance. An international comparison between non-crisis and crisis period. Master Thesis of Finance.

Waddock, S. A., \& Graves, S. B. (2006). The impact of mergers and acquisitions on corporate stakeholder practices. Journal of Corporate Citizenship, 22(2006), 91-109.

\section{Copyrights}

Copyright for this article is retained by the author(s), with first publication rights granted to the journal.

This is an open-access article distributed under the terms and conditions of the Creative Commons Attribution license (http://creativecommons.org/licenses/by/4.0/). 